\title{
The effects of colloids or crystalloids on acute respiratory distress syndrome in swine (Sus scrofa) models with severe sepsis: analysis on extravascular lung water, IL-8, and VCAM-1
}

\author{
Rismala Dewi, ${ }^{1}$ Bambang Supriyatno, ${ }^{1}$ Amir S. Madjid, ${ }^{1}$ Gunanti, ${ }^{2}$ Munar Lubis ${ }^{3}$ \\ ${ }^{1}$ Department of Child Health, Faculty of Medicine, Universitas Indonesia, Cipto Mangunkusumo Hospital, Jakarta, Indonesia \\ 2 Department of Surgery, Faculty of Veterinary Medicine, Institut Pertanian Bogor, Bogor, Indonesia \\ ${ }^{3}$ Department of Child Health, Faculty of Medicine, Universitas Sumatera Utara, Medan, Indonesia
}

\section{ABSTRAK}

Latar belakang: Acute respiratory distress syndrome (ARDS) merupakan salah satu komplikasi fatal sepsis berat. Penggunaan cairan koloid sebagai cairan resusitasi dapat menurunkan kejadian ARDS karena memiliki berat molekul yang lebih tinggi dibandingkan cairan kristaloid. Peningkatan extravascular lung water (EVLW), kadar interleukin-8 (IL-8) dan vascular cell adhesion molecule-1 (VCAM-1) telah diteliti sebagai indikator penting yang berperan dalam patogenesis ARDS. Tujuan penelitian ini adalah mengungkap pengaruh cairan kristaloid atau koloid terhadap kejadian ARDS pada model hewan coba babi dengan sepsis berat, serta menganalisis pengaruh cairan kristaloid atau koloid terhadap peningkatan EVLW, IL-8, dan VCAM-1.

Metode: Penelitian ini merupakan studi eksperimental acak tersamar ganda, dilakukan di Laboratorium Bedah Eksperimental, Fakultas Kedokteran Hewan, IPB, dengan menggunakan 22 ekor babi sehat, berat badan 8-12 kg. Subjek dialokasikan secara acak menjadi dua kelompok, yaitu yang mendapatkan cairan resusitasi koloid atau kristaloid. Setelah pemberian endotoksin, klinis ARDS, EVLW, IL-8, dan VCAM-1 dipantau saat sepsis, sepsis berat, 1 jam, dan 3 jam pascaresusitasi cairan. Analisis data menggunakan uji Wilcoxon, uji Kolmogorov-Smirnov, uji Mann-Whitney, uji $t$ tidak berpasangan.

Hasil: ARDS kategori ringan lebih banyak terdapat pada kelompok koloid, sedangkan ARDS kategori sedang lebih banyak pada kelompok kristaloid. Peningkatan EVLW lebih sedikit terjadi pada kelompok koloid dibandingkan dengan kristaloid pada 1 jam dan 3 jam pasca-resusitasi. Nilai kadar IL-8 dan VCAM-1 tidak berbeda bermakna antara kedua kelompok.

Kesimpulan: Penggunaan cairan koloid sebagai cairan resusitasi tidak menurunkan kemungkinan kejadian ARDS dibandingkan kristaloid. Cairan koloid berhubungan dengan peningkatan EVLW yang lebih rendah dibandingkan dengan cairan kristaloid, tetapi tidak pada kadar IL-8 dan VCAM-1.

\section{ABSTRACT}

Background: Acute respiratory distress syndrome (ARDS) is a fatal complication of severe sepsis. Due to its higher molecular weight, the use of colloids in fluid resuscitation may be associated with fewer cases of ARDS compared to crystalloids. Extravascular lung water (EVLW) elevation and levels of interleukin-8 (IL-8) and vascular cell adhesion molecule-1 (VCAM-1) have been studied as indicators playing a role in the pathogenesis of ARDS. The aim of the study was to determine the effects of colloid or crystalloid on the incidence of ARDS, elevation of EVLW, and levels of IL-8 and VCAM-1, in swine models with severe sepsis.

Methods: This was a randomized trial conducted at the Laboratory of Experimental Surgery, School of Veterinary Medicine, IPB, using 22 healthy swine models with a body weight of 8 to $12 \mathrm{~kg}$. Subjects were randomly allocated to receive either colloid or crystalloid fluid resuscitation. After administration of endotoxin, clinical signs of ARDS, EVLW, IL8 , and VCAM- 1 were monitored during sepsis, severe sepsis, and one- and three hours after fluid resuscitation. Analysis of data using the Wilcoxon test, Kolmogorov-Smirnov test , Mann-Whitney test, unpaired t test.

Results: Mild ARDS was more prevalent in the colloid group, while moderate ARDS was more frequent in the crystalloid group. EVLW elevation was lower in the colloid compared to the crystalloid group. There was no significant difference in IL-8 and VCAM-1 levels between the two groups.

Conclusion: The use of colloids in fluid resuscitation does not decrease the probability of ARDS events compared to crystalloids. Compared to crystalloids, colloids are associated with a lower increase in EVLWI, but not with IL-8 or VCAM-1 levels.

Keywords: ARDS, colloid, crystalloid, EVLW, sepsis

pISSN: 0853-1773 • eISSN: 2252-8083 • http://dx.doi.org/10.13181/mji.v25i1.1204 • Med J Indones. 2016;25:33-8

- Received 05 Feb 2015 • Accepted 17 Feb 2016

Corresponding author: Rismala Dewi, dewi22juli@gmail.com

Copyright @ 2016 Authors. This is an open access article distributed under the terms of the Creative Commons Attribution-NonCommercial 4.0 International License (http://creativecommons.org/licenses/by-nc/4.0/), which permits unrestricted non-commercial use, distribution, and reproduction in any medium, provided the original author and source are properly cited. 
Severe sepsis is a major cause of morbidity and mortality in children in intensive care. In the United States, the number of reported cases of severe sepsis is 42,000 per year $(0.56$ case per 1,000 population per year). ${ }^{1}$ In 2009 , in Cipto Mangunkusumo Hospital, Jakarta, out of 502 pediatric patients requiring intensive care, $19 \%$ had sepsis and $54 \%$ of them died from sepsisrelated causes. ${ }^{2}$ Acute respiratory distress syndrome is a serious complication of sepsis, occuring in $60 \%$ of sepsis cases with a mortality rate of $30 \%$ to $60 \%{ }^{3-5}$

Increased capillary permeability is a leading cause of acute respiratory distress syndrome (ARDS). In relation to this, an elevation in extravascular lung water (EVLW) is an essential part of the pathogenesis of ARDS, although it may also arise through other mechanisms. ${ }^{6,7}$ A rise in hydrostatic pressure will increase the risk of lung edema and eventually worsen the ARDS. ${ }^{8}$ To date, optimal fluid management in patients with severe sepsis has been a controversial issue. Some studies have reported that crytalloid solutions increase EVLW, while colloids do not. ${ }^{8-10}$ Colloid administration has been reported to diminish EVLW elevation, as well as interleukin-8 (IL-8) and vascular cell adhesion molecule-1 (VCAM-1), inflammatory markers that play a role in ARDS. ${ }^{9}$ Since studies on administration of colloid or crystalloid fluid in pediatrics patient are still scarce, we decided to do this study. There are also very limited number of studies on the role of EVLW on ARDS and validation of EVLW in children is more complex.

The pathogenesis of ARDS is complex and remains poorly understood. Histopathologic examination is needed to explain the process; however, due to ethical considerations such examination could not be performed in live pediatric patients with ARDS. Therefore, we used a swine animal model due to its similarities with humans in hemodynamic and respiratory properties, as well as in the pulmonary intravascular macrophage system. ${ }^{10}$ This study aims to observe the effects of colloid and crystalloid solutions on EVLW, IL-8, and VCAM-1 in swine models with severe sepsis and ARDS.

\section{METHODS}

This was an experimental study using swine (Sus scrofa) models held at the Departments of Surgery and Radiology of the School of Veterinary Medicine, Institut Pertanian Bogor, and the Biochemistry and Pathological Anatomy Laboratory of the Medical School, Universitas Indonesia, Cipto Mangunkusumo Hospital, Jakarta, in January to August 2014. Subjects were 11 males and 11 females, two to three months old swine models weighing $8 \mathrm{~kg}$ to $12 \mathrm{~kg}$, equivalent to a human child aged one to three years. The swines were declared healthy by veterinarian and have undergone an adjustment and isolation phase. Animals having veterinarian-confirmed heart sound abnormalities and cardiac defects diagnosed based on chest radiography were excluded.

Swines fulfilling the inclusion criteria were randomized into two groups labeled as "solution A" (Gelatin, Gelofusin ${ }^{\circledR}$.) and "solution B" (Ringer Acetate Maleate, Ringerfundin ${ }^{\circledR}$ ). We used block randomization using random number tables as well as blinding. The study protocol has been approved by the animal ethics committee of the school of veterinary medicine, Institut Pertanian Bogor and the medical research ethics committee of the medical school, Universitas Indonesia (No. 005/KEH/SKE/VI/2014)

Experimental models were prepared in a confinement laboratory with accountable hygiene and standardized feeds (bran, curd pulp, and grass) according to the Guide for the Care and Use of Animals in Agricultural Research and Teaching (1999). ${ }^{10}$ Animal treatments were performed by experienced professionals. Acclimatization, antihelminthics $(5 \mathrm{mg} / \mathrm{kg}$ of oral oxfendazole), and antibiotics (6 to $11 \mathrm{mg} / \mathrm{kg}$ of intramuscular oxytetracyclin) were completed prior to the surgical procedure. Swines were anesthetized with $20 \mathrm{mg} / \mathrm{kg}$ of intramuscular $10 \%$ ketamine $\mathrm{HCl}$ and $2 \mathrm{mg} / \mathrm{kg}$ of intramuscular $2 \%$ xylazine $\mathrm{HCl}$. Following airway intubation, they underwent femoral artery catheterization for pulse index contour cardiac output (PiCCO) as well as central venous catheterization through the internal jugular vein. The animals' vital signs and hemodynamic parameters were monitored throughout the study. Afterwards, administration of $50 \mathrm{mg} / \mathrm{kg}$ of endotoxin from Eschericia coli lipopolysaccharidewere performedintravenously. Then, clinical signs of ARDS, EVLW (PiCCO), IL-8 (pig Elisa), and VCAM-1 (pig Elisa) were observed during sepsis, during severe sepsis, and one- and three hours after fluid resuscitation. 
We observed the swines at the beginning of the study when they were healthy, during sepsis, during severe sepsis, one hour and three hours post-resuscitation, and ended with euthanasia and necropsy. All data were documented in special study forms. The clinical determination of ARDS was based on The Berlin definition criteria. The Berlin definition was established to facilitate the diagnosis of ARDS by categorizing ARDS into three groups based on the degree of hypoxemia which were mild, moderate, and severe. Data analysis was done using SPSS v.20.0 (SPSS Inc., Chicago). Changes in each parameter were compared between the colloid and crystalloid group using unpaired t-test and Mann-Whitney. A $p$ value of $<0.05$ was considered statistically significant.

\section{RESULTS}

Several obstacles were obtained in this study, including the provision of swine models and the animals susceptibility to stress. A number of swines died during the adjustment phase or fell ill during the study. Two subjects died prior to the three-hour-post-resuscitation monitoring. Therefore, we were unable to determine when the clinical diagnosis of ARDS was established in these subjects. Nevertheless, they were still included in this study, using histopathology from necropsy specimens as the sole method of determination of ARDS. Due to these drop-outs, we also obtained a diminished sample size for the comparison of clinically determined ARDS in the colloid and crystalloid group. However, we still obtained an adequate number of subjects when using histopathologic findings and lung injury score as parameters to diagnose ARDS.

\section{Characteristics of study subjects}

We obtained 22 subjects with an equivalent maleto-female ratio. Baseline subject characteristics in the colloid and crystalloid groups were comparable.

There was no significant difference in the clinical manifestations of sepsis between the colloid and crystalloid groups (Table 2). Our results show that hemodynamic responses before receiving fluid resuscitation were similar in both groups. Therefore, any differences observed after fluids administration were solely due to treatment effect.

\section{EVLW elevation in the colloid and crystalloid group}

The increase in EVLW was measured at the point when severe sepsis present, then one hour and three hours after fluid resuscitation. EVLW increase was significantly higher in the crystalloid group compared to the colloid group, both at one hour and three hours post-resuscitation.

Table 1. Characteristics of subjects

\begin{tabular}{lcc}
\hline & \multicolumn{2}{c}{ Results } \\
\cline { 2 - 3 } Variable & $\begin{array}{c}\text { Colloid group } \\
(\mathrm{n}=11)\end{array}$ & $\begin{array}{c}\text { Crystalloid group } \\
(\mathrm{n}=11)\end{array}$ \\
\hline Gender & & \\
$\quad$ Male, $\mathrm{n}(\%)$ & $6(54.5)$ & $5(45.5)$ \\
$\quad$ Female, $\mathrm{n}(\%)$ & $5(45.5)$ & $6(54.5)$ \\
$\begin{array}{l}\text { Body weight (kg), mean } \\
\text { (SD) }\end{array}$ & $9.4(1.36)$ & $9.6(1.57)$ \\
Body length (cm), mean & $70.4(4.50)$ & $69.2(4.35)$ \\
\hline
\end{tabular}

(SD)

\begin{tabular}{|c|c|c|}
\hline $\begin{array}{l}\text { Heart rate (beats/minute), } \\
\text { mean (SD) }\end{array}$ & $110.3(6.42)$ & $108.4(6.15)$ \\
\hline \multicolumn{3}{|l|}{ Blood pressure (mmHg) } \\
\hline Systolic, mean (SD) & $107.3(7.73)$ & $104.5(7.93)$ \\
\hline Diastolic, mean (SD) & $64.7(9.60)$ & $67.4(9.21)$ \\
\hline MAP (mmHg), mean (SD) & $78.8(7.33)$ & $79.9(7.92)$ \\
\hline $\begin{array}{l}\text { Respiratory rate (breaths/ } \\
\text { minute), mean (SD) }\end{array}$ & $31.2(2.86)$ & $29.6(5.59)$ \\
\hline $\begin{array}{l}\text { Temperature }\left({ }^{\circ} \mathrm{C}\right) \text {, mean } \\
(\mathrm{SD})\end{array}$ & $36.7(0.59)$ & $37.2(0.40)$ \\
\hline \multicolumn{3}{|l|}{ Peripheral blood examination } \\
\hline $\begin{array}{l}\text { Hemoglobin (g/dl), mean } \\
\text { (SD) }\end{array}$ & $11.2(0.78)$ & $11.3(1.23)$ \\
\hline $\begin{array}{l}\text { Hematocrite (\%), mean } \\
\text { (SD) }\end{array}$ & $34.9(1.8)$ & $36.9(4.5)$ \\
\hline $\begin{array}{l}\text { Erythrocyte }\left(10^{6} / \mu \mathrm{L}\right) \text {, } \\
\text { mean }(\mathrm{SD})\end{array}$ & $3.7(0.65)$ & $4.3(1.04)$ \\
\hline $\begin{array}{l}\text { Leukocyte }\left(10^{3} / \mu \mathrm{L}\right) \text {, mean } \\
\text { (SD) }\end{array}$ & $16.7(2.94)$ & $17.1(3.69)$ \\
\hline $\begin{array}{l}\text { Thrombocyte }\left(10^{3} / \mu \mathrm{L}\right) \text {, } \\
\text { mean (SD) }\end{array}$ & 361.5 (110.72) & 407.2 (112.9) \\
\hline $\begin{array}{l}\text { Serum creatinine }(\mathrm{mg} / \mathrm{dL}) \text {, } \\
\text { mean }(\mathrm{SD})\end{array}$ & $0.76(0.22)$ & $0.72(0.24)$ \\
\hline $\begin{array}{l}\text { Serum albumin }(\mathrm{g} / \mathrm{dL}) \text {, } \\
\text { mean }(\mathrm{SD})\end{array}$ & $3.5(0.27)$ & $3.9(0.62)$ \\
\hline $\begin{array}{l}\text { Random blood glucose } \\
\text { (mg/dL), median (IQR) }\end{array}$ & $211.0(86-362)$ & $117.0(33-461)$ \\
\hline
\end{tabular}

$\mathrm{SD}=$ standard deviation, $\mathrm{IQR}=$ interquartile range 


\section{Biomarkers in sepsis and ARDS}

Figure 1 shows the values of IL- 8 and VCAM- 1 before and after endotoxin administration. Within the respective groups, there was a significant rise in IL-8 before and after endotoxin administration to induce sepsis. In contrast, VCAM-1 shows no significant changes following sepsis induction. No significant differences in IL-8 and VCAM-1 was found between groups.

\section{ARDS according to the Berlin definition}

Table 4 shows the distribution of ARDS severity in the colloid and crystalloid groups based on The Berlin definition. Moderate ARDS was more prevalent in the crystalloid group, while mild ARDS had a bigger proportion in the colloid group. However, we were unable to demonstrate

Table 2. Clinical manifestation of sepsis in colloid and crystalloid group

\begin{tabular}{lcc}
\hline & \multicolumn{2}{c}{ Results } \\
\cline { 2 - 3 } Variable & $\begin{array}{c}\text { Colloid group } \\
(\mathrm{n}=11)\end{array}$ & $\begin{array}{c}\text { Crystalloid group } \\
(\mathrm{n}=11)\end{array}$ \\
\hline $\begin{array}{l}\text { Heart rate (beats/minute), } \\
\text { mean (SD) }\end{array}$ & $131.4(14.18)$ & $128.3(4.92)$ \\
$\begin{array}{l}\text { Respiratory rate (breaths/ } \\
\text { minute), mean }(\mathrm{SD})\end{array}$ & $38.8(4.73)$ & $38.2(9.32)$ \\
$\begin{array}{l}\text { Temperature }\left({ }^{\circ} \mathrm{C}\right), \text { mean } \\
(\mathrm{SD})\end{array}$ & $38.1(0.75)$ & $38.5(1.09)$ \\
$\begin{array}{l}\text { Leukocyte }\left(10^{3} / \mu \mathrm{L}\right), \text { mean } \\
(\mathrm{SD})\end{array}$ & $6.3(2.71)$ & $6.0(2.81)$ \\
\hline
\end{tabular}

$\mathrm{SD}=$ standard deviation

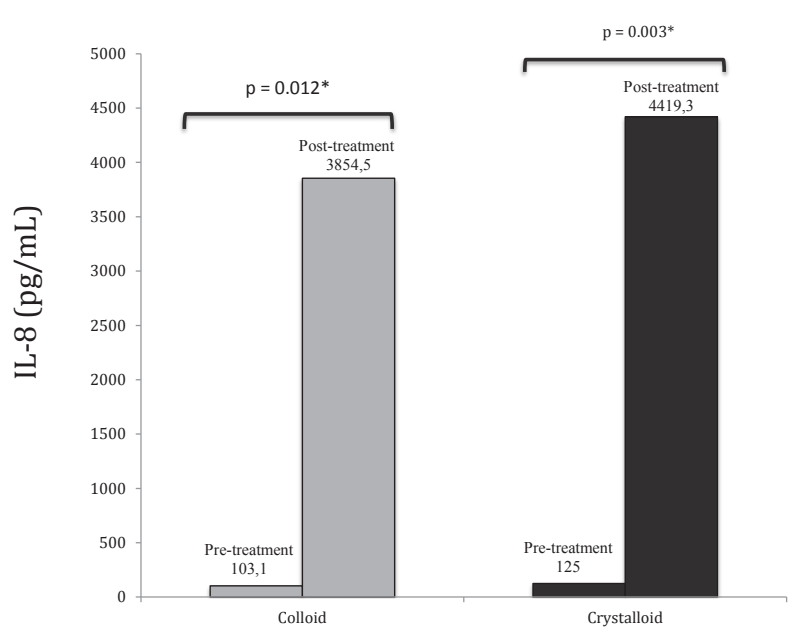

the statistical significance of this difference $(p=0.699)$. We had a small number of subjects in each group, but if the difference in ARDS severity we obtained was due to a real effect, then the magnitude of this difference would have been clinically important.

Table 3. Comparison of EVLW elevation between colloid and crystalloid group

\begin{tabular}{lccc}
\hline \multirow{2}{*}{$\begin{array}{l}\text { Elevation of EVLW } \\
(\mathrm{mL} / \mathrm{kg})\end{array}$} & $\begin{array}{c}c \\
\text { Colloid } \\
(\mathrm{n}=11)\end{array}$ & $\begin{array}{c}\text { Crystalloid } \\
(\mathrm{n}=11)\end{array}$ & $\mathrm{p}$ \\
\cline { 2 - 3 } & $1.00(0-2.00)$ & $3.00(0-$ & $0.030^{*}$ \\
$\begin{array}{l}\text { one hour post- } \\
\text { resuscitation, median }\end{array}$ & & $11.00)$ & \\
$(\mathrm{IQR})$ & & & \\
three hour post- & $2.7(2.34)$ & $6.3(4.12)$ & $0.034^{\dagger}$ \\
resuscitation, mean & & & \\
$(\mathrm{SD})$ & & & \\
\hline
\end{tabular}

*Mann-Whitney test, †Unpaired t-test, $\mathrm{SD}=$ standard deviation, $\mathrm{IQR}=$ interquartile rang

Table 4. The distribution of ARDS severity at the end of monitoring in the colloid and crystalloid groups

\begin{tabular}{lccc}
\hline & \multicolumn{3}{c}{ Groups } \\
\cline { 2 - 3 } ARDS category & $\begin{array}{c}\text { Colloid group } \\
(\mathrm{n}=9)\end{array}$ & $\begin{array}{c}\text { Crystalloid group } \\
(\mathrm{n}=9)\end{array}$ & $\mathrm{p}^{*}$ \\
\hline Normal, n (\%) & $1(50)$ & $1(50)$ & 0.699 \\
Mild, n (\%) & $7(64)$ & $4(36)$ & 0.699 \\
Moderate, n (\%) & $1(20)$ & $4(80)$ & 0.699 \\
Severe, n (\%) & $0(0)$ & $0(0)$ & 0.699 \\
\hline
\end{tabular}

*Kolmogorov-Smirnov test

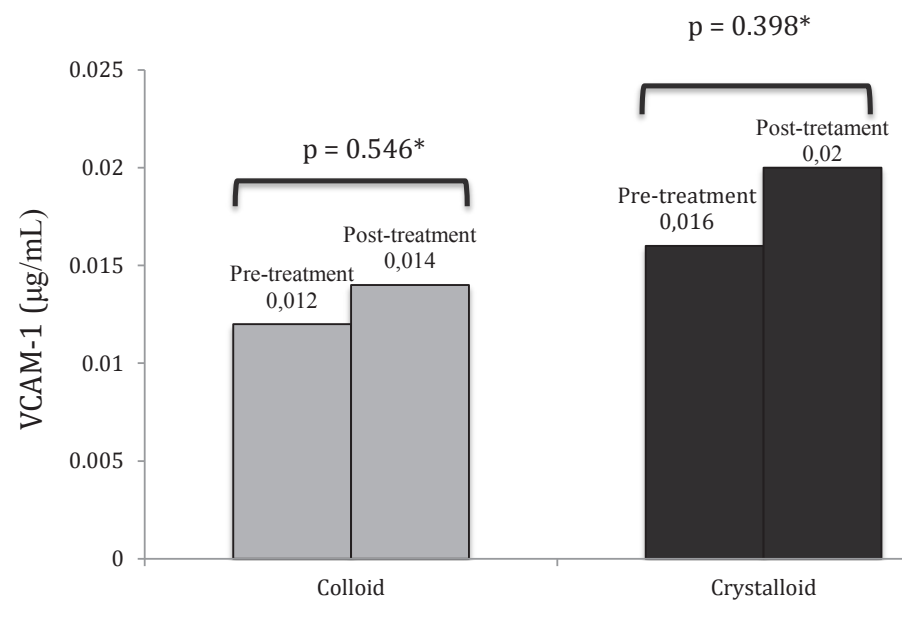

*Wilcoxon signed rank test

Figure 1. Comparison of IL-8 and VCAM-1 at pre-and-post-treatment between the colloid and crystalloid groups 


\section{DISCUSSIONS}

\section{EVLW elevation in the colloid and crystalloid group}

The use of EVLW to reflect an increase in hydrostatic edema or inflammation has been reported in a number of recent studies. ${ }^{11-13}$ Some studies in adults have reported an association between the rise in EVLW, the occurence of ARDS, and the mortality of patients with severe sepsis. $^{14,15}$ In the present study, EVLW elevation in the colloid group was smaller than in the crystalloid group (Table 3). The increase in lung capillary permeability in sepsis causes a shifting of fluid into the interstitial space, resulting in EVLW elevation. Both colloid and crystalloid administration add to increased EVLW, although with colloid administration a smaller increase was seen than in crystalloid administration, due to the ability of colloids to remain longer within the intravascular compartment. In the crystalloid group, the EVLW increase was apparent starting at one hour post-resuscitation, due to the shifting of the fluid out of the intravascular compartment, causing edema in the interstitial space with only $20 \%$ remaining intravascularly. The elevation became even more marked at three hours postresuscitation. On the other hand, in the colloid group the rise in EVLW only started to noticeably appear at three hour post-resuscitation. ${ }^{16,17}$ This implies that there is less interstitial edema with resuscitation with colloids compared to crystalloids.

\section{Biomarkers in sepsis and ARDS}

In sepsis, among the most important cytokines are IL- 1 and tumor necrosis factor-a (TNF- $\alpha$ ), which stimulate the production of IL-8 from various cells such as endothelial cells, macrophages, neutrophils, alveolar epithelial cells, and fibroblasts. ${ }^{18-21}$ In the present study, IL-8 appears to increase after endotoxin administration in both groups (Figure 1). This finding is consistent with that of previous studies reporting that only IL-8 increased consistently, at the beginning and during severe sepsis and that the increase remained within 24 hours [44.3 interquartile range (IQR) 17.8205) $\mathrm{pg} / \mathrm{mL}$ and 757 (IQR 221-1,898) pg/mL; $\mathrm{p}=0.002] .{ }^{19}$ IL- 8 can be detectable as early as ten minutes post-lypopolysaccharide (LPS) administration and in growth media is secreted after three hours of exposure. Therefore, IL-8 is a reliable early marker during sepsis due to bacterial infection. ${ }^{22}$

In this study, IL-8 appears to increase after endotoxin administration in colloid group 103.1 (IQR 0.2 to 350 ) $\mathrm{pg} / \mathrm{mL}$ and 3,854.5 (IQR 2,968.9 to $4,574.0) \mathrm{pg} / \mathrm{mL}$, with a significant difference $\mathrm{p}=0.012$. Likewise the crystalloid group, with a value of 125 (IQR 0.3 to 546.9 ) $\mathrm{pg} / \mathrm{mL}$ and 4,419.3 (IQR 945.2 to $4,847.3$ ) $\mathrm{pg} / \mathrm{mL}, \mathrm{p}=0.003$. Our findings are consistent with previous studies reporting that synthetic colloids have specific antiinflammatory effects, including decreasing postischemic leukocyte-endothelium interaction and platelet adhesion. Synthetic colloids have special characteristics which can influence vascular permeability and inflammation; nevertheless, the clinical relevance of such characteristics has not yet been fully explored. The mechanism through which colloids affect IL-8 levels is also poorly understood. ${ }^{16,17}$

We did not find a significant increase in VCAM-1 both in the colloid and crystalloid groups after endotoxin administration. Two pathways have been postulated for the elevation of VCAM- 1 in severe sepsis, both mediated by the release of inflammatory mediators: alveolar endothelial injury and the formation of neutrophilthrombocyte complexes resulting in inflammation and an increase in thromboxane-A2. In our subjects, it appears that only inflammation and mild injury to the vascular endothelium have occured, therefore still inadequate to cause neutrophil extravasation into the interstitial space. In addition, the increase in the expression of VCAM- 1 can occur up to 6 hours after exposure, ${ }^{16}$ beyond the length of monitoring in the present study. A longer monitoring time may be necessary to observe further lung injury such that a more marked difference can be seen.

In conclusion, the use of colloids, compared to crystalloids, in fluid resuscitation does not decrease the probability of ARDS events. However, the use of colloids is associated with a lower increase in EVLW and a lower mean lung injury score. Colloid or crystalloid use does not appear to affect IL-8 and VCAM-1 levels. In vivo studies comparing colloid and crystalloid fluid resuscitation are needed in children with severe sepsis. 


\section{Conflict of interest}

The authors affirm no conflict of interest in this study.

\section{REFERENCES}

1. Watson RS, Carcillo JA, Linde-Zwirble WT, Clermont G, Lidicker J, Angus DC. The epidemiology of severe sepsis in children in the United States. Am J Respir Crit Care Med. 2003;167(5):695-701.

2. Medical Record Department of Child Health, Cipto Mangunkusumo Hospital. Unpublished Data. 2008. Indonesian.

3. Monahan LJ. Acute respiratory distress syndrome. Curr Probl Pediatr Adolesc Health Care. 2013;43:278-84.

4. Dahlem P, van Aalderen WM, Bos AP. Pediatric acute lung injury. Paediatr Respir Rev. 2007;8(4):348-62.

5. Abraham E, Singer M. Mechanism of sepsis-induced organ dysfunction. Crit Care Med. 2007;35(10):2408-16.

6. Kirov MY, Kuzkov VV, Bjertnaes LJ. Extravascular lung water in sepsis. Intensive Care Med. 2005;6:449-60.

7. Martin GS, Eaton S, Mealer M, Moss M. Extravascular lung water in patients with severe sepsis: a prospective cohort study. Crit Care. 2005;9(2):R74-82.

8. Orbegozo Cortes D, Santacruz C, Donadello K, Nobile L, Taccone FS. Colloids for fluid resuscitation: what is their role in patients with shock?. Minerva Anestesiol. 2014;80(8):963-9.

9. Cordemans C, De laet I, Van Regenmortel N, Schoonheydt K, Dits H, Huber W, et al. Fluid management in critically ill patients: the role of extravascular lung water, abdominal hypertension, capillary leak, and fluid balance. Ann Intensive Care. 2012;2(Suppl1):S1-12.

10. Jackson P, Cockroft P. Handbook of pig medicine. 1st ed. New York: Elsevier Health Sciences; 2007. p. 1-45.

11. Khemani RG, Wilson DF, Esteban A, Ferguson ND. Evaluating the Berlin definition in pediatric ARDS. Intensive Care Med. 2013;39(12):2213-6.
12. Matute-Bello G, Downey G, Moore BB, Groshong SD, Matthay MA, Slutsky AS, et al. An official American Thoracic Society workshop report: features and measurements of experimental acute lung injury in animals. Am J Respir Cell Mol Biol. 2011;44(5):725-38.

13. Chung FT, Lin HC, Kuo CH, Yu CT, Chou CL, Lee KY, et al. Extravascular lung water correlates multiorgan dysfunction syndrome and mortality in sepsis. PLoS One. 2010;5(12):e15265.

14. Lubrano R, Cecchetti C, Elli M, Tomasello C, Guido G, Di Nardo M, et al. Prognostic value of extravascular lung water index in critically ill children with acute respiratory failure. Intensive Care Med. 2011;37(1):124-31.

15. Berkowitz DM, Danai PA, Eaton S, Moss M, Martin GS. Accurate characterization of extravascular lung water in acute respiratory distress syndrome. Crit Care Med. 2008;36(6):1803-9.

16. Jacob M, Bruegger D, Rehm M, Welsch U, Conzen $P$, Becker BF. Contrasting effects of colloid and crystalloid resuscitation fluids on cardiac vascular permeability. Anesthesiology. 2006;104(6):1223-31.

17. van der Heijden M, Verheij J, van Nieuw Amerongen GP, Groeneveld AB. Crystalloid or colloid fluid loading and pulmonary permeability, edema, and injury in septic and nonseptic critically ill patients with hypovolemia. Crit Care Med. 2009;37(4):1275-81.

18. Mehta D, Malik AB. Signaling mechanisms regulating endothelial permeability. Physiol Rev. 2006;86(1):279-367.

19. Remick DG. Interleukin-8. Crit Care Med. 2005;33(12Suppl):S466-7.

20. Pierrakos C, Vincent JL. Sepsis biomarkers: a review. Crit Care. 2010;14(1):R15.

21. Fanelli V, Vlachou A, Ghannadian S, Simonetti U, Slutsky AS, Zhang H. Acute respiratory distress syndrome: new definition, current and future therapeutic options. J Thorac Dis. 2013;5(3):326-34.

22. Macdonald SP, Stone SF, Neil CL, van Eeden PE, Fatovich DM, Arendts G, et al. Sustained elevation of resistin, NGAL and IL-8 are associated with severe sepsis/ septic shock in the emergency department. PLoS One. 2014;9(10):e110678. 